\title{
A survey for plant-growth-promoting rhizo- bacteria and symbionts associated with crop plants in the Okavango region of Southern Africa
}

\author{
Jann Grönemeyer, Dirk Berkelmann, Tabo Mubyana-John, Daniel Haiyambo, Percy \\ Chimwamurombe, Bruce Kasaona, Thomas Hurek \& Barbara Reinhold-Hurek*
}

\begin{abstract}
Regions in the Okavango catchment and delta such as highlands of Angola, the Kavango region of Namibia, and the Okavango Delta region of Botswana, although rich in plant diversity and density, have not produced significant yields when cropped by small scale farmers in the region. This phenomenon may be due to many factors among which is low nitrogen and other crop nutrients availability. This region due to its richness in flora may harbour bacteria which play a major role in plant nutrient availability. However, some of these rhizobacteria can be isolated and re-inoculated on crop plants to improve crop yields. Thus a survey on root nodulation of local pulses such as Vigna unguiculata, V. subterranea, and Phaseolus vulgaris, in the Chitembo area of Angola and the Kavango region of Namibia was carried out. Nodulated plants and putatively symbiotic bacteria were detected from a range of sites for all species. In Namibia, isolation of putative plant-growth-promoting rhizobacteria (PGPRs) was done on cereal crops and from other indigenous plants on farmland and from pristine areas. In Botswana, phosphate solubilizing bacteria were isolated from the roots of grasses in the floodplains and assayed for their ability to solubilize soil phosphate with the intention of using them to increase yields in sorghum (Sorghum vulgare). In total, 46 bacterial strains were isolated from nodules of legumes from Namibia, while 37 strains were isolated from Angola. Additionally, 32 strains of plant associated rhizobacteria were obtained from cereals or natural plants from the Kavango region in Namibia, and further ten isolates were selected from the Seronga region in Botswana. The large number of bacteria generated by this survey may contain some bacteria that may promote plant growth and improve soil fertility.
\end{abstract}

Keywords: bambara groundnut; cowpea; nodule; Pennisetum glaucum; phosphate solubilizing bacteria; Rhizobium; sorghum.

Pesquisa sobre rizobactérias promotoras do crecimento de plantas e simbiontes associados com cereais, na região do Okavango no sul da África

Resumo: Regiões na bacia e no delta do Okavango, como os planaltos de Angola, a região de Kavango da Namíbia e a região do delta do Okavango de Botsuana, embora ricas em diversidade e densidade de plantas, não produziram safras significativas quando cultivadas por agricultores de pequena escala na região. Este fenômeno pode ser devido a vários fatores, entre os quais a baixa disponibilidade de nitrogênio e outros nutrientes agrícolas. Essa região, devido à sua riqueza em flora, pode abrigar bactérias que desempenham um papel importante na disponibilidade de nutrientes nas plantas. No entanto, algumas destas rizobactérias podem ser isoladas e reinoculadas em culturas para melhorar seu rendimento. Assim, foi realizado um estudo sobre a nodulação das raízes de plantas locais, como a "Vigna unguiculata", "V. subterranea" e "Phaseolus vulgaris", em Chitembo na área Angolana e no Kavango na região da Namíbia. Plantas noduladas e bactérias putativamente simbióticas foram detectadas a partir de uma variedade de locais para todas as espécies. Na Namíbia, o isolamento de rizobactérias putativas promotoras do crescimento de plantas (PGPRs) foi feito em culturas de cereais e de outras plantas indígenas em terras agrícolas e em áreas intocadas. Em Botsuana, bactérias solubilizadoras de fosfato foram isoladas das raízes de gramíneas nas várzeas e analizadas por sua capacidade de solubilizar fosfato do solo, com a intenção de usá-las para aumentar a produtividade na cultura do sorgo (Sorghum vulgare). No total, 46 cepas de bactérias foram isoladas de nódulos de leguminosas na Namíbia, enquanto 37 foram isoladas em Angola. Além disso, 32 cepas de plantas associadas a rizobactérias foram obtidas a partir de cereais ou plantas naturais da região de Kavango na Namíbia e outras 10 cepas isoladas foram selecionadas da região de Seronga em Botsuana. O grande número de bactérias geradas por essa pesquisa pode conter algumas bactérias que podem promover o crescimento das plantas e melhorar a fertilidade do solo.

Palavras-chave: Amendoim bambara; bactérias de solubilização de fosfato; feijão-caupi; milheto; nódulo Rhizobium; Pennisetum glaucum; sorgo.

Received: 27 July 2013 - Accepted: 19 December 2013

\section{Introduction}

The predominant agriculture paradigm based on improved varieties of common staple crops in high-input systems has not succeeded addressing food insecurity and malnutrition e.g. in Sub-Saharan Africa (Rudebjer et al. 2013), where over 200 million people $(28 \%$ of the population) were undernourished in 2005-2007 (FAO, 2010). Yield variability and risk for crop failure in Africa's rainfed agriculture systems contribute to factors that explain difficulties in adopting new technologies (Ogada et al. 2010). These risks are predicted to increase in many areas in
Southern Africa due to climate change, as projections suggest a decline in land area suitable for cultivation of crops (Lane \& Jarvis 2007). On the other hand, demand for staple crops like maize is currently increasing in Africa due to changes in eating habits, with limited production and increasing imports. 
Low crop productivity is often a problem faced in smallholder farming systems in Sub-Saharan and Southern Africa. Subsistence agriculture with low agrochemical inputs is widespread in the greater Okavango catchment regions of the Okavango basin in Angola, Namibia and Botswana. For example in smallholder's farms of the Kavango region of Namibia, fields are not irrigated, herbicides as well as pesticides and fertilizers are not used, and crop yields are very low (Pröpper et al. 2010).

Low yields are often associated with declining soil fertility and low input by biologically fixed nitrogen (see below), depending on biological and environmental factors (Dakora \& Keya 1997). The availability of nitrogen affects the productivity of crops and cereals worldwide in all ecosystems. Nitrogen fertilizer is the most widely used resource, of which one third is lost through emission of greenhouse gasses and leaching, causing adverse environmental impacts. Unfortunately, the majority of African small farmers are not able to afford the high mineral fertilizer prices (Yanggen et al. 1998) albeit there is a growing need for mineral $\mathrm{N}$ fertilizers (World bank, 2008). Low cost and sustainable technical solutions compatible with the socioeconomic conditions of small farmers are needed to solve soil fertility and yield problems (Chianu et al. 2011).

Nitrogen is unique among the other essential elements because $\mathrm{N}_{2}$ from the atmosphere can be fixed by biological nitrogen fixation (BNF), exclusively carried out by prokaryotes that possess the enzyme nitrogenase. This potential can be employed in nitrogen-fixing symbioses between Fabaceae and rhizobia, but also in other crop systems for a more sustainable agricultural practice. The most important $\mathrm{N}_{2}$-fixing agents in agricultural systems are the symbiotic associations between crop and forage/fodder legumes and rhizobia forming root nodule symbioses. Estimates of $\mathrm{N}$ fixed annually are $>100 \mathrm{~kg}$ $\mathrm{N} /$ ha/year in good-practice farmer's fields (Herridge et al. 2008). However, there is only little published knowledge on rhizobial symbionts of crops from Namibia, Angola, or Botswana (PuleMeulenberg \& Dakora 2007). Given the high cost of fertilizer in Africa and the limited market infrastructure for farm inputs, current research and extension efforts need to be directed to integrated nutrient management, in which legumes
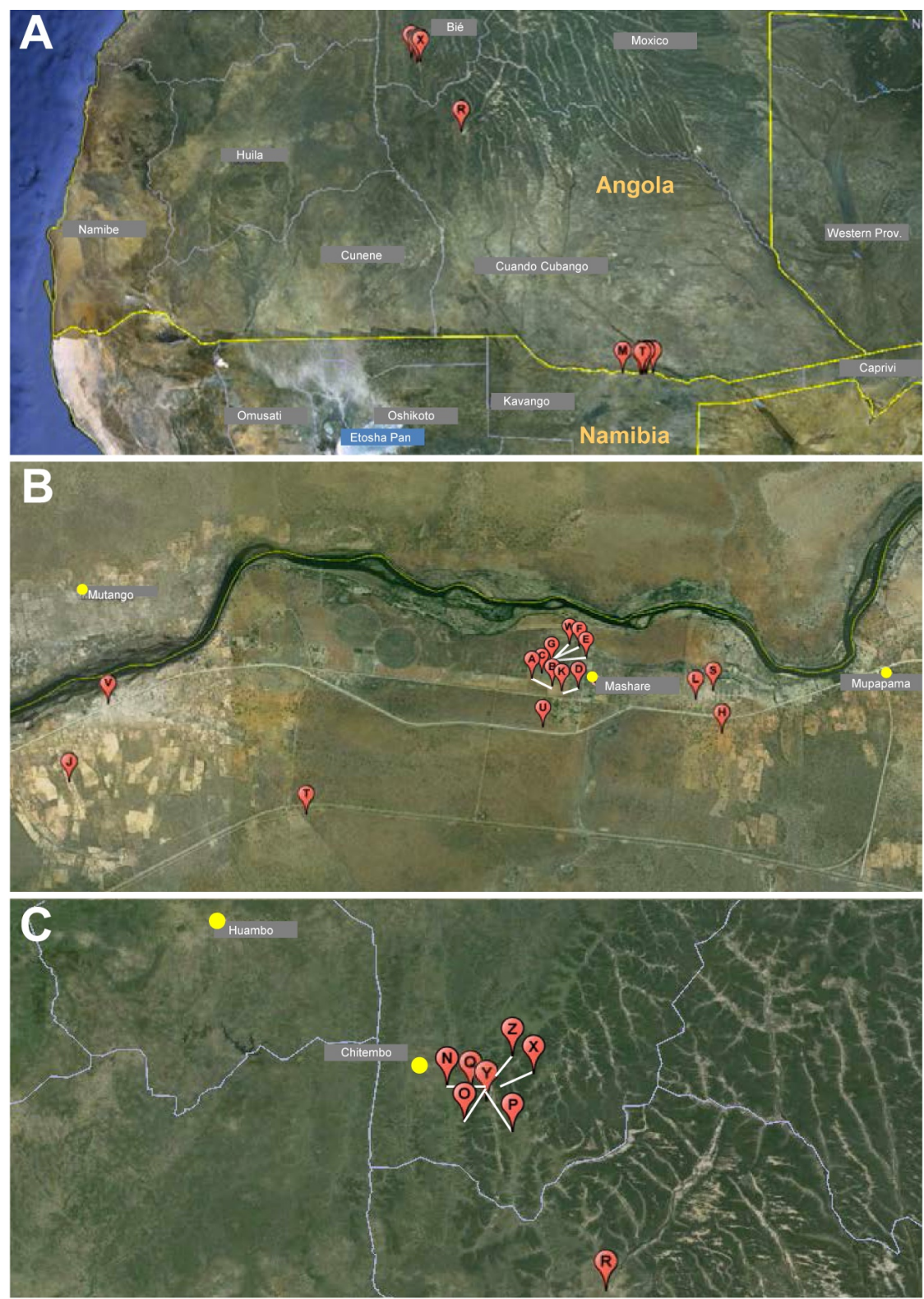

Fig. 1: Overview of the areas of the survey for nodulated grain legumes in Southern Africa. (A) Overview of sampling areas in Angola and Namibia. (B) Close-up of the sampling areas in the Kavango province of Namibia, near Kaiango, Mashare and Mupapama. (C) Close-up of the sampling area in the province of Bié near Kuseke in Angola.Flowchart of the implemented analysis scheme.

play a crucial role. Inoculation with compatible rhizobia resistant to harsh environmental conditions can make BNF a key source for farmers with little income (Smaling et al. 2008).

Additionally, roots support the growth of a variety of microorganisms that may have strong effects on growth or health of plants, not based on BNF. These beneficial bacteria (plant-growthpromoting rhizobacteria, PGPR) may enhance root or plant growth, nutrient uptake, stress resistance or resistance to pathogens by a variety of mechanisms (Adesemoye \& Kloepper 2009,
Desbrosses et al. 2009). Studies on or inoculants for traditional cereal crops in the Kavango area are not available. In a first survey, we isolated and identified endophytes from roots of Namibian maize, Sorghum bicolor and Pennisetum glaucum, which are affiliated to known PGPRs or might even represent new species (Grönemeyer et al. 2012).

Here, we report on a survey for putative symbionts of grain legumes and putative PGPRs of local cereals in the Okavango region, with focus on Namibia and extension to Botswana and Angola. In Botswana where phosphate is one of 
Table 1. Survey of grain legumes for nodulation by rhizobia in Namibia and Botswana. Locations represent sites shown in Figure 1. Samples labeled with "soil" represent trapping experiments from collected soil samples, using the plant species mentioned. NAM, Namibia; ANG, Angola. MADI: Mashare Agricultural Development Institute, test fields for varieties.

\begin{tabular}{|c|c|c|c|c|c|c|}
\hline Country & Location & Coordinates & Plant species & Land use form & $\begin{array}{c}\text { Plant } \\
\text { number }\end{array}$ & Isolates \\
\hline NAM & A & $\begin{array}{l}\text { S17.895486 } \\
\text { E20.211047 }\end{array}$ & Arachis hypogaea & MADI, not irrigated, local race & 1 & 1 \\
\hline NAM & B & $\begin{array}{l}\text { S17.895126 } \\
\text { E20.210972 }\end{array}$ & Arachis hypogaea & MADI, not irrigated, local race & 2 & 1 \\
\hline NAM & $\mathrm{C}$ & $\begin{array}{l}\text { S17.893389 } \\
\text { E20.209500 }\end{array}$ & Vigna unguiculata & MADI, irrigated, local race & 3,4 & 2 \\
\hline NAM & $\mathrm{E}$ & $\begin{array}{l}\text { S17.893125 } \\
\text { E20.210531 }\end{array}$ & Vigna unguiculata & MADI, not irrigated, race from Kenia & 6 & 1 \\
\hline NAM & $\mathrm{F}$ & $\begin{array}{l}\text { S17.892806 } \\
\text { E20.210467 }\end{array}$ & Vigna unguiculata & MADI, not irrigated, dryland conditions, race as 6 & 7 & 2 \\
\hline NAM & G & $\begin{array}{l}\text { S17.892661 } \\
\text { E20.210467 }\end{array}$ & Arachis hypogaea & MADI, field as 7 , race as 1 & 8 & 0 \\
\hline NAM & $\mathrm{H}$ & $\begin{array}{l}\text { S17.90074 } \\
\mathrm{E} 20.23303\end{array}$ & $\begin{array}{l}\text { Vigna subterranea } \\
\text { Vigna unguiculata }\end{array}$ & $\begin{array}{l}\text { Subsistence farmer`s field, dryland agriculture, } \\
\text { Kalahari sands }\end{array}$ & $\begin{array}{c}9 \\
10\end{array}$ & $\begin{array}{l}1 \\
1\end{array}$ \\
\hline NAM & I & $\begin{array}{l}\text { S17.89546 } \\
\text { E20.33150 }\end{array}$ & Vigna unguiculata & $\begin{array}{l}\text { Subsistence farmer`s field, dryland agriculture, old } \\
\text { floodplain soils }\end{array}$ & 14 & 1 \\
\hline NAM & $\mathrm{J}$ & $\begin{array}{l}\text { S17.90719 } \\
\text { E20.14718 }\end{array}$ & Arachis hypogaea & $\begin{array}{l}\text { Subsistence farmer's field, dryland agriculture, } \\
\text { Kalahari sands }\end{array}$ & 16 & 1 \\
\hline NAM & $\mathrm{K}$ & $\begin{array}{l}\text { S17.895881 } \\
\text { E20.212164 }\end{array}$ & $\begin{array}{l}\text { Vigna unguiculata } \\
\text { Arachis hypogaea }\end{array}$ & $\begin{array}{l}\text { MADI, dryland conditions, local race, Kalahari } \\
\text { sands }\end{array}$ & $\begin{array}{l}20-25 \\
26-29\end{array}$ & $\begin{array}{l}2 \\
4\end{array}$ \\
\hline NAM & $\mathrm{H}$ & $\begin{array}{l}\text { S17.90074 } \\
\text { E20.23303 }\end{array}$ & $\begin{array}{l}\text { Vigna unguiculata } \\
\text { Vigna subterranea }\end{array}$ & $\begin{array}{l}\text { Subsistence farmer's field, dryland agriculture, } \\
\text { Kalahari sands }\end{array}$ & $\begin{array}{l}34,35 \\
36-38\end{array}$ & $\begin{array}{l}5 \\
5\end{array}$ \\
\hline NAM & M & $\begin{array}{l}\text { S17.898225 } \\
\text { E19.900658 }\end{array}$ & $\begin{array}{l}\text { Vigna subterranea } \\
\text { Arachis hypogaea } \\
\text { Vigna unguiculata }\end{array}$ & $\begin{array}{l}\text { Subsistence farmer`s field, dryland agriculture, old } \\
\text { floodplain soil, field legumes only }\end{array}$ & $\begin{array}{l}54-56,60 \\
57-59,61 \\
62\end{array}$ & $\begin{array}{l}6 \\
2 \\
0\end{array}$ \\
\hline ANG & $\mathrm{N}$ & $\begin{array}{l}\text { S13.69958 } \\
\text { E17.06752 }\end{array}$ & Vigna unguiculata & Subsistence farmer`s field, dryland agriculture & 40,41 & 4 \\
\hline ANG & $\mathrm{O}$ & $\begin{array}{l}S 13.70122 \\
\mathrm{E} 17.06739\end{array}$ & Phaseolus vulgaris & Subsistence farmer`s field, dryland agriculture & 42 & 2 \\
\hline ANG & $\mathrm{P}$ & $\begin{array}{l}\text { S13.71203 } \\
\mathrm{E} 17.06544\end{array}$ & $\begin{array}{l}\text { Phaseolus vulgaris } \\
\text { Vigna unguiculata }\end{array}$ & Subsistence farmer`s field, dryland agriculture & $\begin{array}{l}43,44 \\
45,46\end{array}$ & $\begin{array}{l}4 \\
5\end{array}$ \\
\hline ANG & Q & $\begin{array}{l}\text { S13.640244 } \\
\text { E16.983867 }\end{array}$ & $\begin{array}{l}\text { Vigna unguiculata } \\
\text { Phaseolus vulgaris }\end{array}$ & $\begin{array}{l}\text { Subsistence farmer`s field, dryland agriculture } \\
\text { Novel field, next to above, older field }\end{array}$ & $\begin{array}{l}47-48,50-51 \\
49\end{array}$ & $\begin{array}{l}5 \\
3\end{array}$ \\
\hline ANG & $\mathrm{R}$ & $\begin{array}{l}\text { S14.662819 } \\
\text { E17.665467 }\end{array}$ & Phaseolus vulgaris & Small field in Menongue & 52,53 & 4 \\
\hline NAM (soil) & $\mathrm{H}$ & $\begin{array}{l}\text { S17.90073 } \\
\text { E20.23300 }\end{array}$ & Vigna subterranea & $\begin{array}{l}\text { Subsistence farmer`s field, dryland agriculture, } \\
\text { Kalahari sands }\end{array}$ & & 4 \\
\hline NAM (soil) & $\mathrm{S}$ & $\begin{array}{l}\text { S17.89518 } \\
\text { E20.23199 }\end{array}$ & $\begin{array}{l}\text { Vigna subterranea } \\
\text { Vigna unguiculata }\end{array}$ & $\begin{array}{l}\text { Subsistence farmer`s field, dryland agriculture, old } \\
\text { floodplain soil }\end{array}$ & & $\begin{array}{l}1 \\
1\end{array}$ \\
\hline NAM (soil) & $\mathrm{T}$ & $\begin{array}{l}\text { S17.91146 } \\
\text { E20.17834 }\end{array}$ & Vigna subterranea & Bushveld, Kalahari sands & & 4 \\
\hline NAM (soil) & $U$ & $\begin{array}{l}\text { S17.89968 } \\
\text { E20.20953 }\end{array}$ & $\begin{array}{l}\text { Vigna unguiculata } \\
\text { Vigna subterranea }\end{array}$ & Bushveld, Kalahari sands & & $\begin{array}{l}1 \\
2\end{array}$ \\
\hline NAM (soil) & V & $\begin{array}{l}\text { S17.89690 } \\
\text { E20.15219 }\end{array}$ & Vigna unguiculata & $\begin{array}{l}\text { Subsistence farmer`s field, dryland agriculture, old } \\
\text { floodplain soil }\end{array}$ & & 2 \\
\hline NAM (soil) & W & $\begin{array}{l}\text { S17.89274 } \\
\text { E20.21068 }\end{array}$ & Vigna subterranea & $\begin{array}{l}\text { Irrigation agriculture, old floodplain soil, maize } \\
\text { field }\end{array}$ & & 1 \\
\hline ANG (soil) & $x$ & $\begin{array}{l}\text { S13.70896 } \\
\text { E17.11225 }\end{array}$ & Vigna subterranea & Fallow after subsistence farming & & 2 \\
\hline ANG (soil) & $\mathrm{Y}$ & $\begin{array}{l}\text { S13.69081 } \\
\text { E17.0633 }\end{array}$ & Vigna subterranea & Subsistence farmer`s field, dryland agriculture & & 1 \\
\hline ANG (soil) & Z & $\begin{array}{l}\mathrm{S} 13.68787 \\
\mathrm{E} 17.101756\end{array}$ & Vigna subterranea & Pristine grassland / bush & & 2 \\
\hline
\end{tabular}


the major limiting elements in the cultivation of sorghum, the staple crop, a study was carried out to isolate phosphate solubilizing bacteria from the rhizosphere of Seronga floodplain grasses.

\section{Materials and Methods}

\section{Time and location of sampling campaigns}

A survey for nodulated grain legumes was carried out in Namibia and Angola in the rainy season. Samples were obtained mainly in the Mashare area during 23.03.24.03.2011. A second campaign in this area was from 25.03.-27.04.2012 and 03.04.2012. Inspection of roots for nodules was also carried out between 30.12.2012-03.01.2013. In Angola, sampling was carried out in the Kuseke area south of Chitembo between 30.03.01.04.2012. Soils for trapping of rhizobia were also collected in the March -April 2012 field trips on the sampling sites. The coordinates of these sampling sites are given in Table 1 , and the locations are shown in Figure 1.

Sampling of plants for PGPR isolation was carried out on selected sites indicated in Table 2 along the Kavango riverine agro-ecology zone in Namibia.

In Botswana, dominant flood plain grasses in Seronga flood plains were selected. The coordinates of the sampling sites are shown in Table 3.

\section{Sampling of nodules and isolation of bacterial symbionts}

Grain legumes (Table 1) from farmer's fields were inspected for root nodules at their root systems. If nodules were present, several nodules per plant were cut off including some adjacent root tissue. They were stored in $2 \mathrm{ml}$ glass vials with silica gel desiccant at room temperature during the campaign, and at $4^{\circ} \mathrm{C}$ upon arrival in Bremen. The cultivation of root nodule bacteria was carried out in the following way: desiccated root nodules were rehydrated in $2 \mathrm{ml}$ of sterile water for four hours at room temperature. They were then surface sterilized by immersion in $70 \%$ ethanol for 30 seconds followed by a washing step in sterile water and immersion in 5\% sodium hypochlorite for two minutes. After six further washing steps, surface sterilized nodules were homogenized with mortar and pestle in

Table 2. Source of bacterial isolates from Namibia with potential for plant growth promotion. Latin name for Mahangu is Pennisetum glaucum.

\begin{tabular}{|c|c|c|c|c|}
\hline Country & $\begin{array}{c}\text { GPS } \\
\text { Coordinates }\end{array}$ & Plant species & Land use form & Isolates \\
\hline Namibia & $\begin{array}{l}17^{\circ} 53^{\circ} 43.80 \mathrm{~S} \\
20^{\circ} 14^{\circ} 05.26 \mathrm{E}\end{array}$ & Mahangu & $\begin{array}{l}\text { Subsistance } \\
\text { farming }\end{array}$ & 8 \\
\hline Namibia & $\begin{array}{l}17^{\circ} 53^{\circ} 49.75 \mathrm{~S} \\
20^{\circ} 09^{\circ} 07.07 \mathrm{E}\end{array}$ & Mahangu & $\begin{array}{l}\text { Subsistance } \\
\text { farming }\end{array}$ & 3 \\
\hline Namibia & $\begin{array}{l}17^{\circ} 55^{\circ} 00.13 \mathrm{~S} \\
20^{\circ} 06^{\prime} 16.14 \mathrm{E}\end{array}$ & Mahangu & $\begin{array}{l}\text { Subsistance } \\
\text { farming }\end{array}$ & 2 \\
\hline Namibia & $\begin{array}{l}17^{\circ} 54^{\circ} 04.40 \mathrm{~S} \\
20^{\circ} 14^{\prime} 14.34 \mathrm{E}\end{array}$ & Mahangu & $\begin{array}{l}\text { Subsistance } \\
\text { farming }\end{array}$ & 3 \\
\hline Namibia & $\begin{array}{l}17^{\circ} 53^{\circ} 43.80 \mathrm{~S} \\
20^{\circ} 14^{\circ} 05.26 \mathrm{E}\end{array}$ & Sorghum bicolor & $\begin{array}{l}\text { Subsistance } \\
\text { farming }\end{array}$ & 2 \\
\hline Namibia & $\begin{array}{l}17^{\circ} 55^{\circ} 00.13 \mathrm{~S} \\
20^{\circ} 06^{\prime} 16.14 \mathrm{E}\end{array}$ & Sorghum bicolor & $\begin{array}{l}\text { Subsistance } \\
\text { farming }\end{array}$ & 4 \\
\hline Namibia & $\begin{array}{l}17^{\circ} 53^{\prime} 38.49 \mathrm{~S} \\
20^{\circ} 09^{\circ} 08.97 \mathrm{E}\end{array}$ & Sporobolus sp. & Pristine & 2 \\
\hline Namibia & $\begin{array}{l}17^{\circ} 53^{`} 33.62 \mathrm{~S} \\
20^{\circ} 14^{`} 56.13 \mathrm{E}\end{array}$ & Sporobolus sp. & Pristine & 3 \\
\hline Namibia & $\begin{array}{l}17^{\circ} 52^{\prime} 30.82 \mathrm{~S} \\
20^{\circ} 15^{\prime} 21.88 \mathrm{E}\end{array}$ & $\begin{array}{c}\text { Phragmites } \\
\text { australis }\end{array}$ & Pristine & 1 \\
\hline Namibia & $\begin{array}{l}17^{\circ} 53^{\prime} 33.62 \mathrm{~S} \\
20^{\circ} 14^{\prime} 56.13 \mathrm{E}\end{array}$ & $\begin{array}{l}\text { Vetiveria } \\
\text { nigritana }\end{array}$ & Pristine & 1 \\
\hline Namibia & $\begin{array}{l}17^{\circ} 53^{\prime} 38.49 \mathrm{~S} \\
20^{\circ} 09^{\circ} 08.97 \mathrm{E}\end{array}$ & $\begin{array}{l}\text { Vetiveria } \\
\text { nigritana }\end{array}$ & Pristine & 1 \\
\hline Namibia & $\begin{array}{l}17^{\circ} 53^{\prime} 33.62 \mathrm{~S} \\
20^{\circ} 14^{\prime} 56.13 \mathrm{E}\end{array}$ & $\begin{array}{c}\text { Ngwena } \\
\text { (Local name) }\end{array}$ & Pristine & 2 \\
\hline
\end{tabular}

100 to $500 \mu 1$ (depending on nodules size) of sterile tap water, and a portion was streaked on modified arabinose gluconate medium (van Berkum 1990). The plates were incubated at $28^{\circ} \mathrm{C}$ for up to 14 days, and pure cultures were obtained by repeated streaking of single bacterial colonies on fresh agar plates.

To confirm the isolates' ability to fix atmospheric nitrogen, a polymerase chain reaction (PCR) based approach targeting the nifH marker gene was carried out. A portion of a bacterial colony was added to $10 \mu 1$ Lyse and Go PCR Reagent (Thermo Scientific, Rockford, USA), and genomic DNA was released following the manufacturer's instructions. $2 \mu \mathrm{L}$ of the lysate served as a template in a PCR consisting of $2.5 \mathrm{U}$ Taq DNA polymerase (Molzym, Bremen, Germany), $5 \mu 1$ 10X PCR Buffer, $50 \mu \mathrm{M}$ of each dNTP, and $0.5 \mu \mathrm{M}$ of each primer FGPH19 and PolR (Poly et al. 2001) in a total volume of 50 $\mu 1$. DNA was amplified in a Biometra TProfessional thermocycler under the cycling conditions described by DembaDiallo et al. (2004). The presence or absence of the $429 \mathrm{bp}$ PCR product was determined on a $1.8 \%$ agarose gel using PstI-digested DNA of Lambda Phage as a size marker.

\section{Sampling of roots and isolation of PGPRs}

Endophytic bacteria were carefully isolated repeatedly from root samples of various plants on selected sites along the Kavango River in Namibia (see Table 2). Pure cultures were obtained and immediately put to long-term storage while further characterization on the isolated bacteria continued. The isolated bacteria were tested for various plantgrowth-promoting features including IAA production, phosphate solubilizing potential and bio-control properties.

In Botswana (Table 3), sampling was done by digging out the entire root systems of the selected plants and then 
Table 3. Source of phosphate solubilizing isolates to be used as PGPR.

\begin{tabular}{|c|c|c|c|c|}
\hline Country & Isolate number & $\begin{array}{c}\text { GPS } \\
\text { coordinates }\end{array}$ & Plant species & Land use form \\
\hline Botswana & S1 & $\begin{array}{l}18^{\circ} 49^{`} 35.48 \mathrm{~S} \\
22^{\circ} 25^{\circ} 55.71 \mathrm{E}\end{array}$ & $\begin{array}{l}\text { Eulesine } \\
\text { africana }\end{array}$ & $\begin{array}{l}\text { Flood plain } \\
\text { grassland }\end{array}$ \\
\hline Botswana & S2 & $\begin{array}{l}18^{\circ} 49^{`} 35.48 \mathrm{~S} \\
22^{\circ} 25^{\circ} 55.71 \mathrm{E}\end{array}$ & $\begin{array}{l}\text { Imperata } \\
\text { cylindrica }\end{array}$ & $\begin{array}{l}\text { Flood plain } \\
\text { grassland }\end{array}$ \\
\hline Botswana & S3 & $\begin{array}{l}18^{\circ} 49^{`} 35.48 \mathrm{~S} \\
22^{\circ} 25^{\circ} 55.71 \mathrm{E}\end{array}$ & $\begin{array}{l}\text { Imperata } \\
\text { cylindrica }\end{array}$ & $\begin{array}{l}\text { Flood plain } \\
\text { grassland }\end{array}$ \\
\hline Botswana & S4 & $\begin{array}{l}18^{\circ} 48^{\circ} 58.46 \mathrm{~S} \\
22^{\circ} 24^{\circ} 53.53 \mathrm{E}\end{array}$ & $\begin{array}{c}\text { Sesbania } \\
\text { seban }\end{array}$ & $\begin{array}{l}\text { Flood plain } \\
\text { grassland }\end{array}$ \\
\hline Botswana & S5 & $\begin{array}{l}18^{\circ} 49^{`} 35.48 \mathrm{~S} \\
22^{\circ} 25^{\circ} 55.71 \mathrm{E}\end{array}$ & $\begin{array}{l}\text { Panicum } \\
\text { maxinium }\end{array}$ & $\begin{array}{l}\text { Flood plain } \\
\text { grassland }\end{array}$ \\
\hline Botswana & S6 & $\begin{array}{l}18^{\circ} 48^{`} 58.46 \mathrm{~S} \\
22^{\circ} 24^{`} 53.53 \mathrm{E}\end{array}$ & Cyperus sp. & $\begin{array}{l}\text { Flood plain } \\
\text { grassland }\end{array}$ \\
\hline Botswana & S8 & $\begin{array}{l}18^{\circ} 47^{\circ} 38.4 \mathrm{~S} \\
22^{\circ} 24^{\prime} 19.7 \mathrm{E}\end{array}$ & $\begin{array}{l}\text { Cynodon } \\
\text { dactylon }\end{array}$ & $\begin{array}{l}\text { Cattle grazing } \\
\text { Flood plain }\end{array}$ \\
\hline Botswana & S9 & $\begin{array}{l}18^{\circ} 49^{`} 35.48 \mathrm{~S} \\
22^{\circ} 25^{\circ} 55.71 \mathrm{E}\end{array}$ & $\begin{array}{c}\text { Urochloa } \\
\text { decumbens }\end{array}$ & $\begin{array}{l}\text { Flood plain } \\
\text { grassland }\end{array}$ \\
\hline Botswana & S10 & $\begin{array}{l}18^{\circ} 49^{\circ} 35.48 \mathrm{~S} \\
22^{\circ} 25^{\circ} 55.71 \mathrm{E}\end{array}$ & $\begin{array}{l}\text { Urochloa } \\
\text { trichophus }\end{array}$ & $\begin{array}{l}\text { Flood plain } \\
\text { grassland }\end{array}$ \\
\hline
\end{tabular}

shaking off the soil to only retain the rhizosphere soil. Each plant was placed in a separate zip lock bag. All the plants were then placed in a cooler box and transferred to the laboratory. Once at the laboratory the roots were excised at the crown and the shoots were sent to the herbarium for identification, while the roots were retained for isolation of phosphate solubilizing bacteria.

\section{Isolation of phosphate solubilizing bacteria}

For the isolation of phosphate solubilizing bacteria (PSB) sterile calcium phosphate agar amended with $0.125 \mathrm{~g}$ of cyclohexamide/L was used (Nautiyal, 1999). Ten gram of each root sample were placed in a sterile conical flask containing $100 \mathrm{~mL}$ of sterile tap water. The mixture was left standing for 15 minutes, with shaking at intervals. A $1 \mathrm{ml}$ aliquot was used to prepare serial dilutions to 10-4. The dilutions were then spread-plated on the solidified calcium phosphate agar and left in an incubator at $25^{\circ} \mathrm{C}$. The plates were checked daily for any phosphate solubilizing ability.

After 5 days, halo zones around certain colonies were observed in some of the plates. The colonies with clear halo zones were considered to be PSB and these colonies were picked up using a sterile
In the Kavango region of Namibia, agriculture is largely dominated by smallholder farms with low crop yields and little developed market chains and food processing. Here as in many African regions, grain legumes can be regarded as "meat for the poor", due to their rich protein content and the relatively low prices of pulses in comparison to meat (Chianu et al. 2011). In our surveys of smallholder farms, cowpea (Vigna unguiculata, local name in Kavango makunde) was the main grain legume grown by farmers (Fig. 2A). In Namibia, also Bambara groundnut (Vigna subterranea, local name nongomene) is planted (Fig. 3A, B), albeit to a lesser extent. It can be regarded as part of neglected and underutilized species which are often local crops that remain important to poor communities' livelihood but are not exploited to their full potential (Rudebjer et al. 2013). Occasionally, peanuts (Arachis hypogaea,

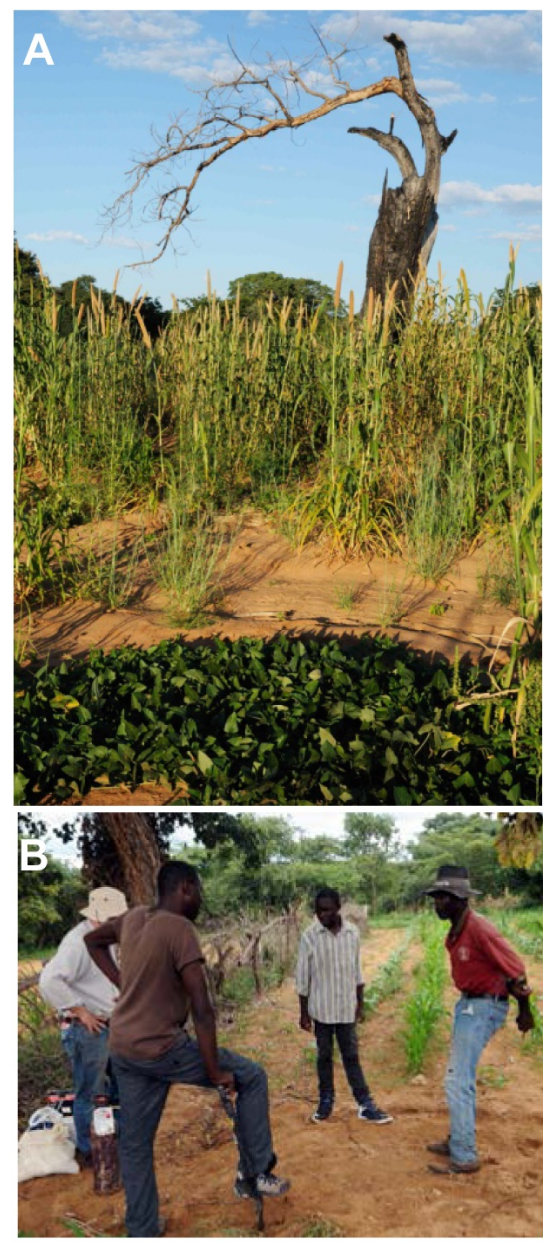

Fig. 2: Intercropping in smallholder farms in the Mashare area in the Kavango region of Namibia. (A) Mahangu and cowpea intercropping. (B) Sampling on a plot for field tests on a traditional smallholder farm. 
local name nongongo) were also found. In the Chitembo area, in addition to cowpea, the common bean (Phaseolus vulgaris) is utilized as well (Fig. 3F).

Common practice was intercropping of grain legumes with local cereals such as mahangu (Pennisetum glaucum), sorghum (Sorghum bicolor), or maize (Fig. 2), where legumes were interspersed in an irregular pattern (Fig. 2A). Farmers mostly used local varieties which they propagated themselves and stored grains for the following season. This dryland agriculture system is rainfed, with planting when the rainy season starts, typically November to December. Smallholders did not use chemical fertilizers or manure or any other input. Thus, nitrogen fixation by legume nodule symbiosis would provide an important input of nitrogen into the farming system.

\section{Survey of grain legumes for root nodulation}

In the wet season of 2011 and 2012, we undertook a survey of grain legumes and their root nodulation in Namibia and Angola. In Namibia, the North of the Kavango province was targeted, particularly the region around Mashare which belongs to the core sites of the TFO (The Future Okavango) project (Fig. $1 \mathrm{~A}, 1 \mathrm{~B})$. The region is characterized by different forms of land use: few pristine woodlands were present; bushveld sites were woody areas used for occasional grazing of cattle; dryland agriculture was the typical form of smallholder farming (see above), and some of these fields had been abandoned (fallows); in small areas near the river, irrigation agriculture with fertilizer inputs was conducted by commercial farmers. In a parallel survey of different land use types and different soils (see Gröngröft et al. 2013), two categories of landscapes and soil types (old flood plains and Kalahari sands) were considered. Soils for trapping (see below) originated from different land use and soil types (Table 1). In Angola, the area for the survey was also one of the core sites of TFO, a rural area dominated by smallholder farms south of Chitembo (Fig. 1, Table 1). Land use types were typically forests and dryland agriculture fields on the summits of hills, horticulture in the wetlands of the valleys, and grassland at the slopes.

Inspection of root systems of pulses in fields of subsistence farmers in the Kavango region often showed a relatively
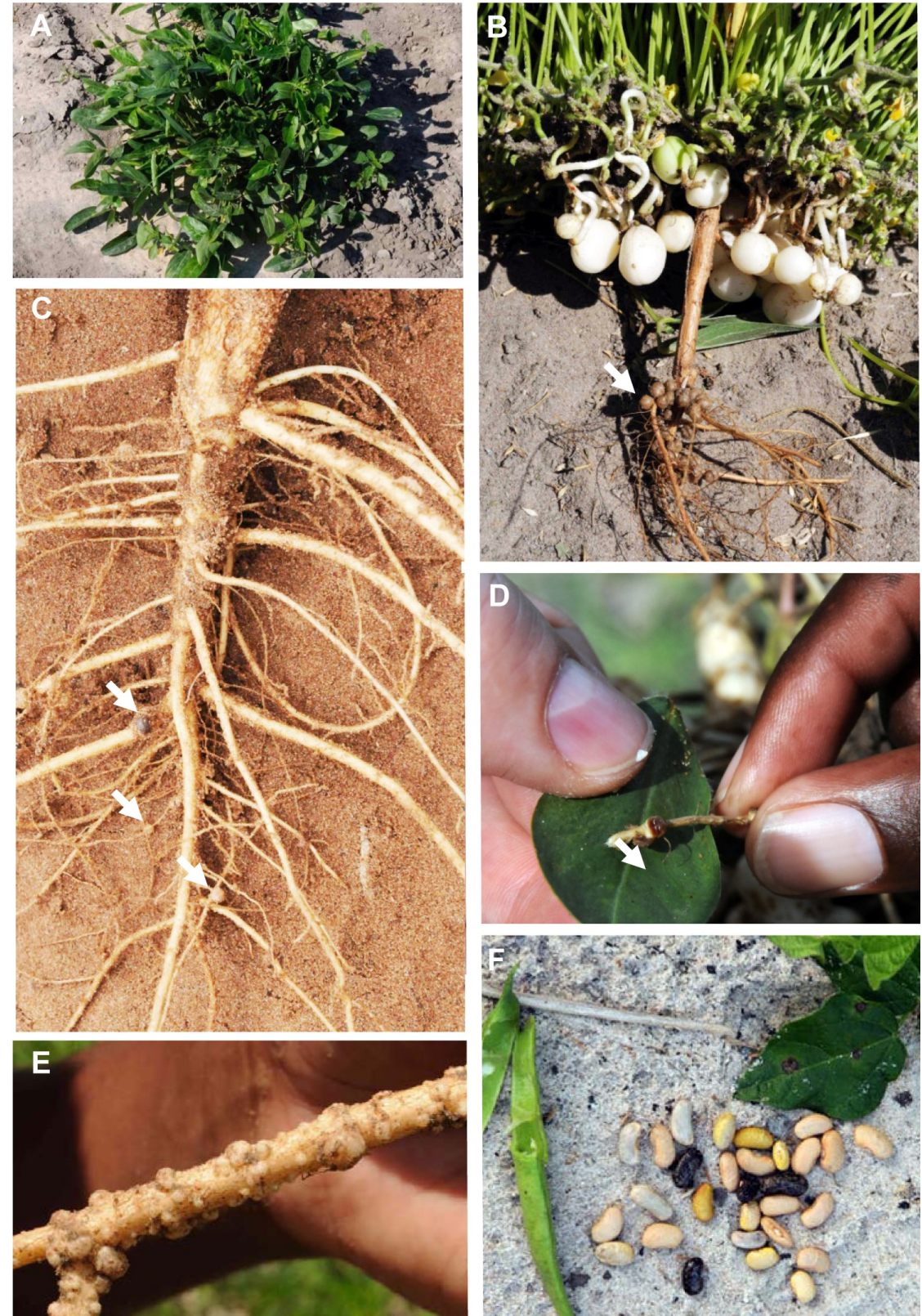

Fig. 3: Examples of nodulated grain legumes detected during the survey in Namibia. (A) Bambara groundnut (Vigna subterranea) plant and (B) well-nodulated root system with groundnuts. (C) Cowpea (Vigna unguiculata) root system and (D) detached root nodule cut open. (E) Well-nodulated roots of cowpea. Arrows point towards examples of root nodules. (F) Beans (Phaseolus vulgaris) cultivated in smallholder farms in Angola.

low degree of nodulation (Fig. 3 C, D), similar observations were made at the Angolan site. Therefore, a survey of traditional legume crops was undertaken for detection of nodulated plants, in order to isolate putatively efficient bacterial symbionts adapted to the soil and climatic conditions. Surveys were carried out in Namibia in the rainy season in December/January or March/April. Generally, nodules were more abundant and less senescent earlier in the season. Most samples originated from the
Mashare area in the Kavango region (Fig. $1 \mathrm{~B}$, Table 1). The widest range of grain legumes was found at the MADI (Mashare Agricultural Development Institute), where test fields were under irrigation or under rainfed (dryland) conditions typical for smallholders' farms. Here, cowpea, Bambara groundnut, peanut, and Lablab purpureus were cultivated. Several of these plants were nodulated, albeit often poorly. However, from several plants and species, diazotrophs could be isolated 
from nodules (Table 1). On some fields of subsistence farmers, nodulated plants appeared to be relatively rare: for example, only from 3 out of 10 inspected individual plants of Bambara groundnut on site $\mathrm{H}$, root nodules could be detected. On the other hand, in a smallholder farmer's field where mainly grain legumes were grown since several years (site M), some root systems were intensely nodulated (Fig. 3 E). Here an enrichment of compatible rhizobia might have occurred over the years.

In total, we could isolate diazotrophs from nodules collected in Southern Africa from several different grain legumes and from different sites: for cowpea, from 9 sites in Namibia and 3 sites in Angola; for Bambara groundnut, from 2 sites in Namibia; for peanut, 5 sites in Namibia; for Phaseolus vulgaris, from 4 sites in Angola (Table 1).

In order to increase the diversity of isolates from the underrepresented crop Bambara groundnut, we carried out trapping experiments. Soil was collected from different regions and land use forms (dryland and irrigated agriculture, bushveld in Namibia; fallow, dryland agriculture and pristine grassland in Angola) and transported to Germany with cooling. Surface sterilized grains of Bambara groundnut or occasionally cowpea were transplanted into the soils under aseptic conditions, and the root systems inspected for nodulation of root systems. This approach was also successful for isolation of diazotrophs (Table 1). Initial characterization of isolates indicated that the most diazotrophs, except for those isolated from Phasaeolus nodules, belonged to Bradyrhizobium spp.

\section{Survey of cereals and native plants for putatively plant-growth- promoting rhizobacteria and phosphate-solubilizing bacteria}

In the Kavango region of Namibia, roots of local cereals like mahangu and sorghum as well as native plants were used for isolation of root-associated bacteria. From 12 different plant samples, 32 isolates were obtained (Table 2).

From roots of grass samples in the Seronga region of Botswana (Table 3), also numerous bacteria were isolated. Many isolates showed different abilities to solubilize phosphate on the different media. Of the many isolates obtained, only nine showed the ability to solubilize phosphate on all the phosphate agar
Table 4. Diameter of zone of clearance for the different isolates with time (days) on potassium phosphate agar. Values are millimeters. Means followed by the same letter in the same column are not significantly different from each other at $5 \%$ according to the Tukey-Kramer test.

\begin{tabular}{|c|c|c|c|c|c|c|c|}
\hline Isolate & $\begin{array}{l}\text { Grass } \\
\text { source }\end{array}$ & $12 \mathrm{~d}$ & $17 \mathrm{~d}$ & $19 \mathrm{~d}$ & $23 \mathrm{~d}$ & $24 \mathrm{~d}$ & $27 d$ \\
\hline S1 & $\begin{array}{l}\text { Eulesine } \\
\text { africana }\end{array}$ & $4 b$ & $4.5 \mathrm{~b}$ & $4.6 b$ & $5.4 b$ & $5.6 b$ & $9 c$ \\
\hline S2 & $\begin{array}{l}\text { Imperata } \\
\text { cylindrica }\end{array}$ & $1 a$ & $2 a$ & $2 a$ & $2 a$ & $2 a$ & $2 a$ \\
\hline S3 & $\begin{array}{l}\text { Imperata } \\
\text { cylindrica }\end{array}$ & $1 \mathrm{a}$ & $2 a$ & $2 a$ & $2 a$ & $2 a$ & $2 a$ \\
\hline S4 & $\begin{array}{l}\text { Sesbania } \\
\text { sesban }\end{array}$ & $1 \mathrm{a}$ & $2 a$ & $2 a$ & $2 a$ & $2 a$ & $2 a$ \\
\hline S5 & $\begin{array}{l}\text { Panicum } \\
\text { maximum }\end{array}$ & $0.6 a$ & $2 a$ & $2 a$ & $2 a$ & $2 a$ & $2 a$ \\
\hline S6 & Cyperus sp. & $0.4 a$ & $1 a$ & $2 a$ & $2 a$ & $2 a$ & $2 a$ \\
\hline S8 & $\begin{array}{l}\text { Cynodon } \\
\text { dactylon }\end{array}$ & $4 b$ & $5 b$ & $7 b$ & $8 c$ & $8 c$ & $8 c$ \\
\hline s9 & $\begin{array}{c}\text { Urochloa } \\
\text { decumbens }\end{array}$ & $2 a$ & $5 b$ & $6 b$ & $6 b c$ & $7 c$ & $7 b c$ \\
\hline S10 & $\begin{array}{l}\text { Urochloa } \\
\text { trichophus }\end{array}$ & $2 a$ & $4 b$ & $5 b$ & $5 b$ & $6 b c$ & $6 b c$ \\
\hline
\end{tabular}

media used. Maximum solubilization was observed on potassium phosphate agar medium. Table 4 shows the solubilization ability of the different isolates on potassium phosphate agar.

Botswana soils due to the low rainfall are often slightly alkaline and contain cations which form complexes with phosphorus. Such P deficiencies are very common in most Botswana soils. Phosphorus also forms insoluble complexes with other cations such as aluminium, magnesium, iron and potassium in soil (Thompson \& Troeh 2005). It is, therefore, very crucial that any isolate that is intended to be used in the production of a phosphate solubilising biofertilizer should be able to solubilise different phosphate complexes. As such in this study the solubization ability of the isolates was also tested on different agar media i.e., potassium phosphate, magnesium phosphate, iron phosphate, and aluminium phosphate. And only those which showed the ability to solubilize all the phosphates will be selected for further studies.

\section{Conclusions}

Our survey has generated a large number of bacteria which may contribute to promote plant growth and soil fertility. Inspection of root systems of grain legumes in smallholder's fields showed large variations in root nodule symbioses, ranging from poorly or rarely to intensely nodulated. Isolation of putatively symbiotic bacteria may help to develop inoculants adapted to the crops and the harsh environmental conditions. Considering that the soil nutrient status in these areas is generally poor and especially low in $\mathrm{N}$ content, the role microorganisms in enhancing crop production cannot be ignored or overstated. More work is thus required in this regard to design bioformulations that can be deployed in the areas to boost crop production. Moreover, indigenous grasses in Seronga flood plains flourish in environments where crops show serious $\mathrm{P}$ deficiencies, probably because they habour P-solubilising bacteria which they use in acquiring P. In future research, the isolates' ability to solubilise phosphate complexes could be exploited for crop growth. 


\section{Acknowledgements}

The work was done mainly in the framework of the TFO (The Future Okavango) consortium within subproject SP04, and partially in the SASSCAL (Southern African Science Service Centre for Climate Change and Adaptive Land Management) consortium. Research was funded by the BMBF (German Ministry for Education and Research) by a by grant 01LL0912G to B.R.-H., P.C. and T.M-J., and by grant 01 LG1201D to B. R.-H. We would like to thank Robert Mukuya (Namibia) for assistance in communication with farmers. Materials were collected in Namibia with Research and Collection permits 1569/2011 and $1635 / 2011$ and export permits 83786 and 87372 from the Ministry of Environment and Tourism, Windhoek, Namibia, and from Angola with a permit from Universidade José Eduardo dos Santos, Huambo.

\section{References}

Adesemoye, A.O., Kloepper, J.W. (2009): Plant-microbes interactions in enhanced fertilizer-use efficiency. - Applied Microbiology and Biotechnology 85: 1-12. CrossRef

Chianu, J.N., Nkonya, E.M., Mairura, F.S., Chianu, J.N., Akinnifesi, F.K. (2011): Biological nitrogen fixation and socioeconomic factors for legume production in Sub-Saharan Africa. - In: Lichtfouse, E., Hamelin, M., Navarrete, M., Debaeke, P. [Eds.]: Sustainable Agriculture 2: 309-329. Dordrecht: Springer.

Dakora, F.D., Keya, S.O. (1997): Contribution of legume nitrogen fixation to sustainable agriculture in SubSaharan Africa. - Soil Biology \& Biochemistry 29: 809-817. CrossRef

Demba Diallo, M., Willems, A., Vloemans, N., Cousin, S., Vandekerckhove, T.T., de Lajudie, P., Neyra, M., Vyverman, W. Gillis, M., van der Gucht, K. (2004): Polymerase chain reaction denaturing gradient gel electrophoresis analysis of the $\mathrm{N}_{2}$-fixing bacterial diversity in soil under Acacia tortilis ssp. raddiana and Balanites aegyptiaca in the dryland part of Senegal. - Environmental Microbiology 6: 400-415. CrossRef

Desbrosses, G., Contesto, C., Varoquaux, F., Galland, M. Touraine, B. (2009): PGPR-Arabidopsis interactions is a useful system to study signalling pathways involved in plant developmental control. - Plant Signaling \& Behavior 4: 321-323. CrossRef

FAO (2010): The state of food insecurity in the world. Addressing food insecurity in protracted crises. Food and Agriculture Organization of the United Nations, Rome, Italy.

Grönemeyer, J.L., Burbano, C.S., Hurek, T., Reinhold-Hurek, B. (2012): Isolation and characterization of root-associated bacteria from agricultural crops in the Kavango region of Namibia. - Plant \& Soil 356: 67-82. CrossRef

Gröngröft, A., Luther-Mosebach, J., Landschreiber, L., Kowalski, B. (2013): A method for yield assessment on dryland agricultural fields. - Biodiversity \& Ecology 5: 279-286. CrossRef

Herridge, D.F., Peoples, M.B., Boddey, R.M. (2008): Global inputs of biological nitrogen fixation in agricultural systems. - Plant and Soil 311: 1-18.

Lane, A., Jarvis, A. (2007): Changes in climate will modify the geography of crop suitability: agricultural biodiversity can help with adaptation. - SAT eJournal ICRISAT 4: 1-12.

Nautiyal, C.S. (1999): An efficient microbiological growth medium for screening phosphate solubilizing microorganisms. - FEMS Microbiology Letters 170: 265-270.

Ogada, M.J., Nyangena, W., Yesuf, M. (2010): Production risk and farm technology adoption in the rainfed semiarid lands of Kenya. - African Journal of Agricultural and Resource Economics 4: 159-174.

Poly, F., Monrozier, L.J., Bally, R. (2001): Improvement in the RFLP procedure for studying the diversity of nifH genes in communities of nitrogen fixers in soil. Research in Microbiology 152: 95-103. CrossRef

Pule-Meulenberg, F., Dakora, F.D. (2007): Assessing the symbiotic dependency of grain and tree legumes on $\mathrm{N}_{2}$ fixation for their $\mathrm{N}$ nutrition in five agro-ecological zones of Botswana. - Symbiosis 48: 68-77. CrossRef

Pröpper, M., Gröngröft, A., Falk, T., Eschenbach, A., Fox, T., Gessner, U., Hecht, J., Hinz, M.O., Hoettich, C., Hurek, T., Kangombe, F.N., Keil, M., Kirk, M., Clever, M., Mills, A., Mukuya, R., Namwoonde, N.E., Overmann, J., Petersen, A., Reinhold-Hurek, B., Schneiderat, U., Strohbach, B.J., LückVogel, M., Wisch, U. (2010): Causes and perspectives of land-cover change through expanding cultivation in Kavango. In: Jürgens, N., Schmiedel, U., Hoffman, T. [Eds.] Biodiversity in Southern Africa 3: Implications for landuse and management. Hess, Göttingen, Windhoek, pp. 2-31.

Rudebjer, P., Chakeredza, S., Dans, A., Ekaya, W., Ghezae, N., Aboagye, L. N., Kwapata, M., Njoroge, M., Padulosi, S. (2013): Beyond commodity crops: Strengthening young scientists' capacity for research on underutilized species in Sub-Saharan Africa. - Acta
Horticulturae (ISHS) 979: 577-589.

Smaling, E. M. A., Roscoe, R., Lesschen, J. P., Bouwman, A. F., and Comunello, E. (2008): From forest to waste: assessment of the Brazilian soybean chain, using nitrogen as a marker. Agriculture, Ecosystems \& Environment 128: 185-97. CrossRef

Thompson, L.M.,Troeh, F. R. (2005): Soils and soil fertility. 6th ed. Blackwell Publishing Company, USA, pp. 231-247.

van Berkum, P. (1990): Evidence for a third uptake hydrogenase phenotype among the soybean bradyrhizobia. Applied and Environmental Microbiology 56: 3835-3841.

World Bank (2008): World Development Report: Agriculture for Development, World Bank, Washington D.C.

Yanggen, D., Kelly, V. Reardon, T. Naseem, A. (1998): Incentives for fertilizer use in Sub-Saharan Africa: A review of empirical evidence on fertilizer response and profitability. International Development Working Paper 70, Department of Agricultural Economics, Michigan State University, East Lansing, MI, USA.

\section{Affiliations}

Jann Grönemeyer

(jannegroenemeyer@gmx.de), Dirk

Berkelmann (s_vs2gf3@uni-bremen.de),

Thomas Hurek (thurek@uni-bremen.de),

Barbara Reinhold-Hurek* (breinhold@) uni-bremen.de)

Department of Microbe-Plant Interactions,

University of Bremen Postfach 330440

28334 Bremen, GERMANY

Daniel Haiyambo (haiyambodan@ gmail.com), Percy Chimwamurombe (pchimwa@gmail.com)

Department of Biological Sciences, University of Namibia (UNAM)

P. Bag 13301

Windhoek, NAMIBIA

Bruce Kasaona

(kasaonab@mawf.gov.na)

Mashare Agricultural Development

Institute

Private Bag 2096

Rundu, NAMIBIA

Tabo Mubyana-John (mubyanat@mopipi.ub.bw)

Departement of Biological Sciences, University of Botswana

P/B 0022

Gaborone, BOTSWANA

* Corresponding author 